\title{
Fatty acid profile of meat, diurnal changes in volatile fatty acids, rumen fluid parameters, and growth performance in Korean native (Hanwoo) steers fed high- and low-forage diets supplemented with chromium-methionine
}

\author{
Bae-Hun Lee1, Jalil Ghassemi Nejad', Byong-Wan Kim¹, Sang-Jip Ohh'1, Kyung-Il Sung ${ }^{1}$
}

${ }^{1}$ Kangwon National University, College of Animal Life Sciences, Chuncheon, Republic of Korea.

\begin{abstract}
The objective of this study was to determine the effects of forage level in diets supplemented with chromium-methionine (Cr-Met) on rumen fluid parameters, meat fatty acid composition, and performance of Korean beef (Hanwoo) steers. Twenty-three Hanwoo steers were used in this experiment. A completely randomized design and repeated measurements were used to analyze the data set. Beef steers were fed diets containing high (10 head; average body weight $(\mathrm{BW})=525.1 \pm 27.5$; forage:concentrate $(\mathrm{F}: \mathrm{C})=60: 40)(60 \mathrm{~F})$ and low $(13 \mathrm{head}$; average $\mathrm{BW}=531.8 \pm 32.4 ; \mathrm{F}: \mathrm{C}=40: 60 \mathrm{ratio})$ (40F) forage diets supplemented with Cr-Met for $60 \mathrm{~d}$. Dry matter intake, BW, and feed efficiency were not different between the two treatment groups. Fatty acid composition of meat including myristate, stearate, and gamma linoleate was not different between the two groups; however, palmitate, palimtoleate, and linoleate were higher in $60 \mathrm{~F}$ group than $40 \mathrm{~F}$ group. Ammonia-N showed a higher trend in $40 \mathrm{~F}$ group, whereas $\mathrm{pH}$ demonstrated higher values in $60 \mathrm{~F}$ group. Ruminal acetate was higher in $60 \mathrm{~F}$ group than $40 \mathrm{~F}$ group and maintained a high trend throughout the sampling time, whereas no differences were found in ruminal propionate, butyrate, and valerate between two groups. A high-forage diet (60\%) improves meat quality and has no adverse effects on performance of Hanwoo steers.
\end{abstract}

Key Words: forage level, Hanwoo steers, meat quality

\section{Introduction}

Previous studies in our laboratory have reported improvements in carcass characteristics in Korean native (Hanwoo) steers (Sung et al., 2015), meat fatty acid profile, and performance of Holstein steers (Song, et al., 2013; Ghassemi Nejad et al., 2016) receiving chromiummethionine (Cr-Met) supplementation. In those studies, $400 \mathrm{ppb} / \mathrm{d}$ of Cr-Met supplementation was reported as the optimum level. On the other hand, Sung et al. (2015) reported higher marbling score, rib-eye area, and meat yield index in Hanwoo steers fed a high-forage diet supplemented with $400 \mathrm{ppb} / \mathrm{d}$ of Cr-Met compared with the low-forage diet group. However, to the best knowledge of the authors, the effects of Cr-Met supplementation on daily pattern of rumen fluid parameters including volatile fatty acids (VFA), pH, ammonia-N, and fatty acid composition of meat from Hanwoo steers fed high-and low-forage diets is yet to be investigated.

Received January 15, 2016 and accepted June 1, 2016.

Corresponding author: kisung@kangwon.ac.kr

http://dx.doi.org/10.1590/S1806-92902016000800009

Copyright (c) 2016 Sociedade Brasileira de Zootecnia. This is an Open Access article distributed under the terms of the Creative Commons Attribution License (http://creativecommons.org/licenses/by/4.0/), which permits unrestricted use, distribution, and reproduction in any medium, provided the original work is properly cited.
Monounsaturated fatty acids (MUFA) and saturated fatty acids (SFA) are the main components of the great majority of fatty acids in beef fat. Furthermore, beef fats are among the richest natural sources of conjugated linoleic acid (CLA) and trans-vaccenic acid (Chin et al., 1992), which have been shown to have health benefits for humans (Belury, 2002). Any increase in ruminal starch digestion should be followed by an increase in organic acids that are later converted to glucose, which is a precursor for marbling (Kitchalong et al., 1995; Lindemann et al., 2008). Any discussion of marbling levels should also include the genetic influence. Hence, there might be differences between Holstein and Hanwoo steers. Previous research has shown that forage-finished cattle produce beef with more CLA and n-3 fatty acids compared with grain-finished cattle (French et al., 2000). Melton et al. (1982) found that grassfed cattle beef had a decreased concentration of MUFA and a greater concentration of SFA compared with grain-fed cattle; however, one study found that grass-fed cattle beef had less SFA and more MUFA than grain-fed cattle beef (French et al., 2000). Moreover, it has been reported that $\mathrm{Cr}$ supplementation can be employed to manipulate the quality of meat due to its biological function on body fat and muscle metabolism (Kitchalong et al., 1995; Sung et al., 2015); however, factors such as the level of $\mathrm{Cr}$ supplementation and its source, nutrients, chromium levels in the basal diet, 
breed and species may intervene with these functions (Sung et al., 2015; Ghassemi Nejad et al., 2016). Decreasing diet energy density through increasing forage level may also increase ruminal acetate:propionate ratio and methane energy loss (Merchen et al., 1986; Kinser et al., 1988; Zinn et al., 1994). Therefore, the effects of high- and low-forage diet when supplemented with Cr-Met in diet of Hanwoo steers on rumen fluid characteristics and fatty acid profile of beef were investigated in this study.

\section{Material and Methods}

Animal procedures were approved by the Ethical Committee for Animal Research of Kangwon National University. The experiment site was the Gangwon province $\left(37^{\circ} 55^{\prime} 03.64 " \mathrm{~N}, 127^{\circ} 46^{\prime} 22.71\right.$ "E) in Republic of Korea. Twenty-three Korean native (Hanwoo) steers were used in this experiment and assigned to two treatment groups. The feeding amount of Cr-Met (Innobio Co., Ltd., Shiheung, Korea) to animals was limited to $400 \mathrm{ppb} / \mathrm{cow} / \mathrm{d}$. The duration for the study was two months. Feed was total mixed ration (TMR) including commercial concentrate and forage (alfalfa hay, bermudagrass hay, and rice straw) comprising $16 \pm 0.05 \%$ crude protein (CP) and $78 \pm 12.3$ total digestible nutrients (TDN). Treatments included what follows: steers fed diets that contained $60 \%$ concentrate and $40 \%$ forage supplemented with $400 \mathrm{ppb} / \mathrm{d}$ of Cr-Met (average body weight $(\mathrm{BW})=531.8 \pm 32.4$; low-forage diet) (40F); and steers fed diets that contained $40 \%$ concentrate and $60 \%$ forage supplemented with $400 \mathrm{ppb} / \mathrm{d}$ of Cr-Met ( 10 head; average $\mathrm{BW}=525.1 \pm 27.5$; high-forage diet) (60F). Forages and concentrate were mixed and offered twice daily at $09.00 \mathrm{~h}$ and $18.00 \mathrm{~h}$, according to nutrient requirements of beef cattle (NRC, 2000). Water was available ad libitum throughout the experiment.

For the period of two months, feed was collected twice a month to analyze the common feed ingredients according to methods of AOAC (1990; Table 1). Neutral detergent fiber (NDF) and acid detergent fiber (ADF) contents were analyzed following Goering and Van Soest (1991).

Each day, at $08.30 \mathrm{~h}$, feed intake was measured by subtracting the amount of residue and was calculated by

Table 1 - Chemical composition of feeds

\begin{tabular}{lccccc}
\hline Feed & DM (\%) & OM & CP & NDF & ADF \\
\hline Concentrate & 89.2 & 91.2 & 16.5 & 35.1 & 12.6 \\
Forage & 89.1 & 90.7 & 10.2 & 64.5 & 48.2 \\
\hline
\end{tabular}

DM - dry matter; OM - organic matter; CP - crude protein; NDF - neutral detergent fiber; $\mathrm{ADF}$ - acid detergent fiber.

Concentrate used was commercial pellet concentrate on the farm. Forage included alfalfa hay $(55 \%)+$ bermudagrass $(35 \%)+$ rice straw $(10 \%)$. dividing the two values. Body weights were measured prior to the experiment and monthly. Average daily weight gain was measured subsequently. After $21 \mathrm{~d}$ of adaptation to the diet, for $3 \mathrm{~d}$ nonconsecutively $(24,26$, and $28 \mathrm{~d}$ of each month), rumen contents $(1 \mathrm{~kg})$ were sampled through a rumen cannula ( 2 treatments $\times 2$ animals) to describe the rumen $\mathrm{pH}$, ammonia-N, and VFA content. Sampling was carried out before the morning feeding (defined as $0 \mathrm{~h}$ ) and $0.5,1.5,2,4$, and $7 \mathrm{~h}$ after feeding on each of three nonconsecutive days (days 24, 26, and 28 of each experimental period). The rumen fluid was collected through the cannula and then filtered with four layers of cheese cloth within $1 \mathrm{~min}$ and measured using a digital pH meter (Model 420, S/N 049686, Orion Research, Inc. USA). Ammonia-N (ammonia nitrogen) in the rumen fluid was mensured by disconnecting the upper supernatant of the fluid and then diluting 10 times with automatic water quality analyzer (Quikchem, 8000). Finally, $12 \mathrm{~mL}$ of the diluted fluid was inserted into the centrifuge tube and then centrifuged at $3000 \mathrm{rpm}$ for $15 \mathrm{~min}$.

Volatile fatty acids (VFA; acetate, propionate, butyrate and valerate) of rumen were measured using a gas chromatograph (GC, shimadzu GC-17A, $30 \mathrm{~m} \times 0.25 \mathrm{~mm}$ $\times 0.25 \mu \mathrm{m}$ column). After filtration of the rumen fluid, metaphosphoric acid was added to precipitate proteins, and formic acid (5\%) was used to eliminate the disturbing "ghosting" effect. The clear supernatant obtained after centrifugation (3000 rpm for $10 \mathrm{~min}$ ) was injected directly into the column. The analysis of one rumen sample requires about $8 \mathrm{~min}$, in which the temperatures of injector, column, and detector were $-20{ }^{\circ} \mathrm{C}, 100^{\circ} \mathrm{C}$, and $230{ }^{\circ} \mathrm{C}$, respectively. Depending on the implementation of the column temperature programing, helium $(\mathrm{He})$ as a carrier gas with a flow rate of $7 \mathrm{~mL} / \mathrm{min}$ and hydrogen $\left(\mathrm{H}_{2}\right)$ gas and air oxygen with a flow rate of $15 \mathrm{~mL}$ were used. The split ratio was $1: 30$, and $1 \mu \mathrm{L}$ of the sample was used. For the quantitative determination, a nonautomatic integrator was used. The individual VFA were calculated by comparing with a standard.

Upon completion of the field experiment, five steers per group were slaughtered to measure the fatty acid composition of beef from the loin side. Samples from each steer were frozen at $-20{ }^{\circ} \mathrm{C}$ for $12 \mathrm{~h}$ and thawed prior to analysis. According to the method of lipid extraction (Folch et al., 1957), $6 \mathrm{~g}$ of sample and chloroform/methanol (2:1) solution were homogenized in a $25 \mathrm{~mL}$ homogenizer (Diax 6000 , Heidolph, Germany) at $1100 \times g$ for 30 s. Next $6 \mathrm{~mL}$ of $0.88 \% \mathrm{KCl}$ solution were added to the homogenate, followed by centrifugation at $2500 \times g$ (GS-6R Centrifuge, Beckman, Ramsey, MN, USA) for $10 \mathrm{~min}$. The fluid was filtered through filter paper and lipid was concentrated 
using a nitrogen gas concentrator (MGS-2200, Eyelaa Tokyo Rikakikai Co., Ltd, Tokyo, Japan) following the method of AOAC (1990). Each of the fatty acid methyl ester standards (Sigma-Aldrich Co., Saint Louis, MO, USA) was qualitatively compared with retention time, and the analytic conditions were used for gas chromatography (Agilent 6890N, Agilent Technologies, Santa Clara, CA, USA). For this, a sample of beef and tissue was kept for the split ratio of $1: 10$. The oven injector was heated with $220^{\circ} \mathrm{C}$. A carrier of gas $1 \mathrm{~mL} / \mathrm{min}$ was heated at $150{ }^{\circ} \mathrm{C}$ for one min. A column HP-Innowax $(30 \mathrm{~m}$ length $\times 0.32 \mathrm{id} \times 0.25 \mu \mathrm{m}$ thickness) was kept for a detector temperature of $275{ }^{\circ} \mathrm{C}$. The oven maintained the temperature of $200^{\circ} \mathrm{C}$ to $250{ }^{\circ} \mathrm{C}$ at $3{ }^{\circ} \mathrm{C} / \mathrm{min}$ and $250{ }^{\circ} \mathrm{C}$ for $5 \mathrm{~min}$.

Statistical analysis was carried out using the GLM procedure of SAS (Statistical Analysis System, version 9.1) for a completely randomized design. Duncan's multiple range test was used for ranking treatment means within a significant $\mathrm{F}$ test and means were considered significantly different at $\mathrm{P}<0.05$. Means with probabilities between $0.05<\mathrm{P}<0.10$ reflected a tendency to difference. All the data are reported as the sample mean \pm the standard deviation. Pairwise comparisons between means of different groups were performed using a t-test. The difference between two subsets of data is considered statistically significant if the $\mathrm{t}$-test gives a significance level P (P-value) less than 0.05 .

Rumen fluid parameters including $\mathrm{pH}$, ammonia-N, acetate, propionate, butyrate and valerate were analyzed using PROC MIXED of SAS (Statistical Analysis System, version 9.1) for repeated measurement analysis (Littell et al., 1998) and the means were compared for significance by Tukey's test. The statistical model used for analyses was as follows:

$$
\mathrm{y}_{\mathrm{ijk}}=\mu+\alpha_{\mathrm{i}}+\mathrm{d}_{\mathrm{ij}}+\tau_{\mathrm{k}}+(\alpha \tau)_{\mathrm{ik}}+\mathrm{e}_{\mathrm{ijk}},
$$

in which $y_{i j k}$ is the response at time $k$ on animal $j$ in treatment group $i ; \mu$ is the overall mean; $\alpha_{i}$ is the fixed effect of treatment; $d_{i j}$ is the random effect of animal $j$ in treatment group $\mathrm{i} ; \tau_{\mathrm{k}}$ is a fixed effect of time $\mathrm{k} ;(\alpha \tau)_{\mathrm{ik}}$ is a fixed interaction effect of treatment $i$ with time $k$; and $e_{i j k}$ is random error at time $\mathrm{k}$ on animal $\mathrm{j}$ in treatment $\mathrm{i}$. Variance and covariance assumption structures (AR(1), UN, CS, etc.) were tested, then $\mathrm{AR}(1)$ was selected as the best covariance structure for final analysis.

\section{Results}

Dry matter intake (DMI), body weight, $\mathrm{ADG}$, and FE were not different $(\mathrm{P}>0.05)$ between the two groups (Table 2$)$.

Rumen ammonia-N increased for the first $3 \mathrm{~h}$ of the post-feeding period and then decreased; however, no difference $(\mathrm{P}>0.05)$ was observed between the two treatment groups (Figure 1). Ruminal propionate, butyrate, and valerate showed no differences $(\mathrm{P}>0.05)$ between the two treatment groups (Figure 2).

In the current study, no significant differences $(\mathrm{P}>0.05)$ in composition of fatty acids (myristate, stearate, oleate, and gamma linoleate) were observed. However, linoleate

Table 2 - Growth performance in Hanwoo steers fed high- and lowforage diets supplemented with chromium-methionine

\begin{tabular}{lccc}
\hline \multirow{2}{*}{ Item } & \multicolumn{2}{c}{ Treatment } & \multirow{2}{*}{ P-value } \\
\cline { 2 - 3 } & $40 \mathrm{~F}$ & $60 \mathrm{~F}$ & \\
\hline Initial BW (kg) & $531.8 \pm 32.4$ & $525.1 \pm 27.5$ & 0.43 \\
Final BW (kg) & $578.6 \pm 41.0$ & $571.3 \pm 33.8$ & 0.47 \\
Average daily gain (kg/d) & 0.78 & 0.75 & 0.79 \\
Dry matter intake & & & \\
$\quad$ Concentrate (kg \%DM) & $5.9 \pm 0.2$ & $3.9 \pm 0.2$ & \\
Forage (kg \%DM) & $3.9 \pm 0.3 \mathrm{~b}$ & $5.9 \pm 0.3 \mathrm{a}$ & \\
Total (kg \%DM) & $9.9 \pm 0.3$ & $9.8 \pm 0.4$ & \\
Feed efficiency & $12.8 \pm 0.8$ & $12.7 \pm 0.2$ & 0.57 \\
\hline
\end{tabular}

BW - body weight; DM - dry matter.

Treatments included low-forage diet $(40 \%$ forage; $40 \mathrm{~F})$ and high-forage diet $(60 \%$ forage; $60 \mathrm{~F}$ ) supplemented with $400 \mathrm{ppb} / \mathrm{d}$ of chromium-methionine.

Means \pm standard deviation.

$\mathrm{ab}$ - values within a row with different letters differ significantly at $\mathrm{P}<0.05$.
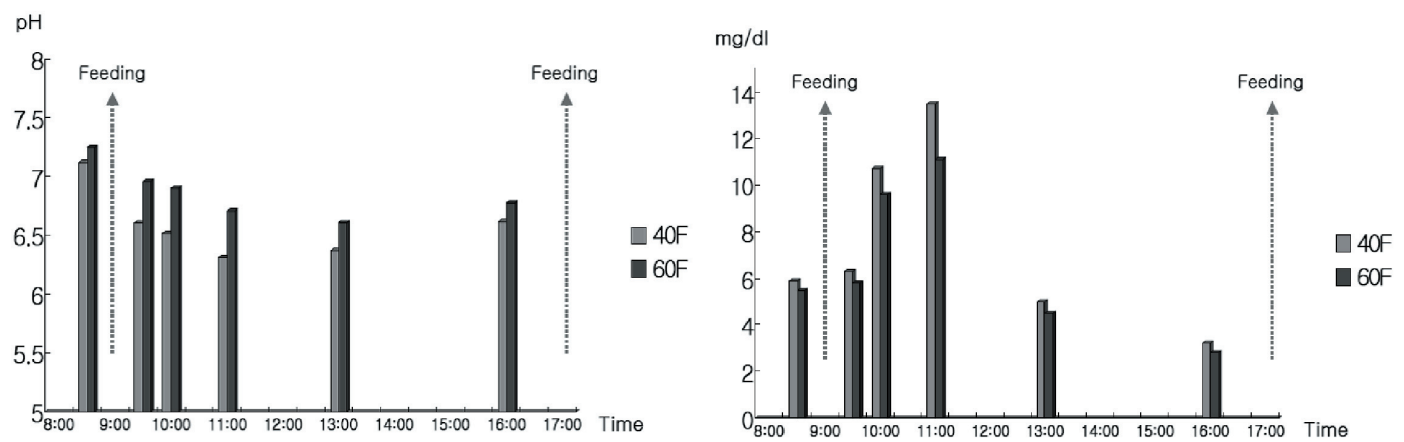

Figure 1 - Diurnal changes in ruminal $\mathrm{pH}$ and ammonia-N in Korean beef steers fed low- and high-forage diets supplemented with chromiummethionine (hourly basis). 
(C18:2n6, $\mathrm{P}<0.05)$, palmitate $(\mathrm{C} 16: 0, \mathrm{P}=0.04)$, and palmitoleate $(\mathrm{C} 16: 1 \mathrm{n} 7, \mathrm{P}=0.03)$ were higher in the $60 \mathrm{~F}$ group than the $40 \mathrm{~F}$ group. Oleate was higher $(\mathrm{P}=0.08)$ in $60 \mathrm{~F}$ group than $40 \mathrm{~F}$ group (Table 3 ).

Cr-Met had no effect $(\mathrm{P}>0.05)$ on saturated, unsaturated, or unsaturated/saturated fatty acids ratio values (Table 3 ).

\section{Discussion}

The similar DM intake in both groups may explain the lack of differences in body weight of steers and consequently ADG and FE between $40 \mathrm{~F}$ and $60 \mathrm{~F}$ groups (Table 2). It appears that the $20 \%$ difference in forage ratio between the two groups could not affect DM intake. Ohh and Lee (2005) concluded that $\mathrm{Cr}$-Met supplementation may not improve body weight of animals. However, by contrast, it has been reported that a higher forage ratio may lead to lower DM intake and lower weight gain in steers in a longer period of growth (Song et al., 2013; Sung et al., 2015).

A timely decrease in $\mathrm{pH}$ post-feeding was predictable in both groups; however, in 60F group, these changes were slighter than in $40 \mathrm{~F}$ group (Figure 1). Because of the higher concentrate ratio in $40 \mathrm{~F}$, a higher amount of soluble carbohydrate may result in lower $\mathrm{pH}$. Ghassemi Nejad et al. $(2012,2016)$ reported lower $\mathrm{pH}$ in Brown Swiss heifer and Holstein steers fed a higher concentrate ratio. Normally, $\mathrm{pH}$ begins to decline post-feeding and continues to fall down after $3 \mathrm{~h}$. Other factors can influence $\mathrm{pH}$ decreasing trend, including but not limited to synchronization between

Table 3 - Fatty acid profile of meat from Hanwoo steers fed high- and low-forage diets supplemented with chromium-methionine

\begin{tabular}{|c|c|c|c|}
\hline \multirow{2}{*}{ Item } & \multicolumn{2}{|c|}{ Treatment } & \multirow{2}{*}{ P-value } \\
\hline & $40 \mathrm{~F}$ & $60 \mathrm{~F}$ & \\
\hline C14:0 (myristate) & $3.63 \pm 0.5$ & $3.9 \pm 0.3$ & 0.53 \\
\hline C16:0 (palmitate) & $28.3 \pm 1.3 b$ & $29.4 \pm 1.4 \mathrm{a}$ & 0.04 \\
\hline C16:1n7 (palmitoleate) & $4.2 \pm 0.7 \mathrm{~b}$ & $5.5 \pm 0.9 \mathrm{a}$ & 0.03 \\
\hline C18:0 (stearate) & $10.3 \pm 1.4$ & $10.2 \pm 1.2$ & 0.73 \\
\hline C18:1n9 (oleate) & $46.9 \pm 2.3$ & $48.2 \pm 2.0$ & 0.08 \\
\hline C18:2n6 (linoleate) & $2.6 \pm 0.6 b$ & $3.6 \pm 0.7 \mathrm{a}$ & 0.03 \\
\hline C18:3n6 (gamma-linoleate) & $0.3 \pm 0.08$ & $0.3 \pm 0.04$ & 0.35 \\
\hline SFA & $46.3 \pm 1.7$ & $46.4 \pm 2.3$ & 0.45 \\
\hline UFA & $54.7 \pm 3.1$ & $54.6 \pm 2.7$ & 0.57 \\
\hline UFA/SFA & $1.2 \pm 0.1$ & $1.2 \pm 0.1$ & 0.91 \\
\hline
\end{tabular}

SFA - saturated fatty acids; USA - unsaturated fatty acids.

Treatments included low-forage diet $(40 \mathrm{~F})$, and high-forage diet $(60 \mathrm{~F})$ supplemented with chromium-methionine.

Means \pm standard deviation.

$\mathrm{ab}$ - values within a row with different letters differ significantly at $\mathrm{P}<0.05$.

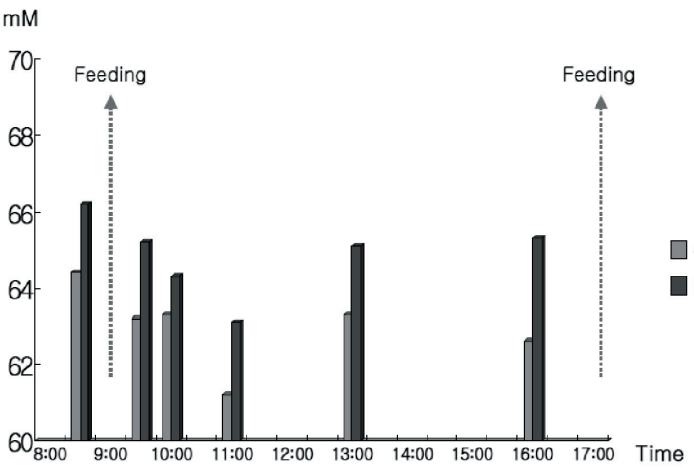

Diurnal pattern of ruminal acetate

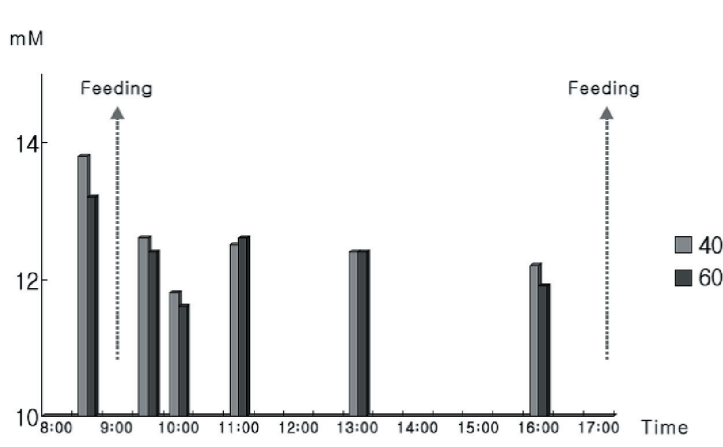

Diurnal pattern of ruminal butyrate

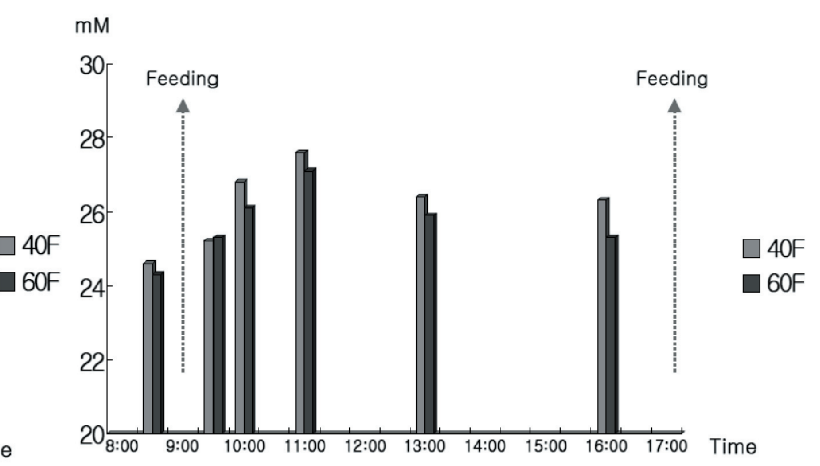

Diurnal pattern of ruminal propionate

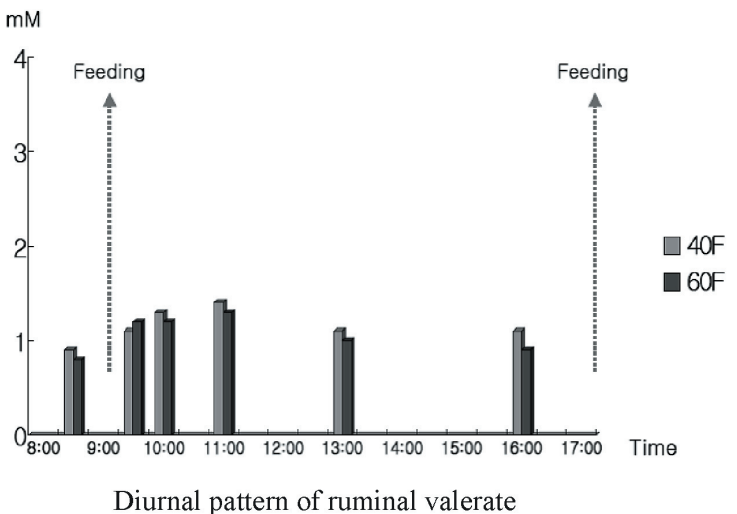

Figure 2 - Diurnal changes in ruminal acetate, propionate, butyrate, and valerate acids in Korean beef steers fed low- and high-forage diets supplemented with chromium-methionine (hourly basis). 
carbohydrate and protein, rate of passage of rumen flora, digesta flow rate, and microbial protein production (Sung et al., 2015; Ghassemi Nejad et al., 2013).

A slight increase in ammonia-N content of rumen $3 \mathrm{~h}$ post-feeding and then a decline were expected due to the availability of nitrogen for both feeding groups. Microbial protein synthesis depends on the availability of nitrogen (or amino acids) and on the degradable carbohydrate content, or on the content of organic matter, and the synchronization in rumen degradation between protein and carbohydrates. If there are high amounts of degradable nitrogen or if the content and rate of carbohydrate degradation in the rumen is reduced or not synchronized with the degradation of protein, losses of nitrogen and/or energy in the rumen could occur (Ghassemi Nejad et al., 2014, 2015).

Ruminal acetate was higher $(\mathrm{P}<0.05)$ in $60 \mathrm{~F}$ compared with 40F group, and remained higher post-feeding (Figure 2). The higher acetate in rumen of $60 \mathrm{~F}$ group can be explained by the higher forage ratio resulting in higher $\mathrm{pH}$ values. Higher $\mathrm{pH}$ values in $60 \mathrm{~F}$ group favor rumen fiber digestibility and maintain stability of $\mathrm{pH}$ in due time (Sung et al., 2015). Moreover, a higher forage ratio in the diet causes higher secretion of saliva, which fosters higher and stable rumen $\mathrm{pH}$. The content of volatile fatty acids and the acetate/propionate ratio may change due to different forage: concentrate ratios. Higher acetic acid may be observed in the rumen fluid of steers fed diets with higher forage ratios, as described by several researchers (Merchen et al., 1986; Kinser et al., 1988; Zinn et al., 1994). Therefore, a large amount of forage in $60 \mathrm{~F}$, which may have resulted in more salivary flow to rumen, provides favorable conditions for the better microbial growth. This may explain the higher acetate production in rumen fluid in $60 \mathrm{~F}$ compared with $40 \mathrm{~F}$ group. In $40 \mathrm{~F}$ group, a higher concentrate ratio is a major factor for lower ruminal $\mathrm{pH}$ and consequently lower acetate production. Zinn and Plascencia (1996) found no significant differences in $\mathrm{pH}$, acetate, propionate, and butyrate between feedlot cattle fed various levels of alfalfa (10\% compared with $30 \%$ ).

The meat fatty acid composition has a promising role in the quality of beef for consumers (Lindemann et al., 2008; Sung et al., 2015; Ghassemi Nejad et al., 2016). Chromium can influence fat mobilization from body stores to meet nutrient requirements. Hence, alterations in some fatty acid compositions can be expected. Chromium-methionine has a high potential to be absorbed through increased digestion in the gastro-intestinal tract (Ohh et al., 2004; Sung et al., 2015; Ghassemi Nejad et al., 2016). The finishing diet strongly influences the fatty acid composition of beef (Smith et al., 2009; Ghassemi Nejad et al., 2016). Zea et al. (2007) reported higher saturated fatty acids (SFA) in animals fed concentrates. Furthermore, Smith et al. (2009) reported that grain feeding stimulates the activity of adipose tissue stearoyl-CoA desaturase in marbling adipose tissue and lowers ruminal isomerization/hydrogenation of dietary polyunsaturated fatty acids (PUFA), resulting in a noticeable increase in monounsaturated fatty acids (MUFA) in beef over time. However, the current study found no differences in the SFA, unsaturated fatty acids (UFA), or UFA/SFA values, which were previously reported in Holstein steers by Ghassemi Nejad et al. (2016).

\section{Conclusions}

Chromium-methionine supplementation in high-forage (60\%) diets can improve meat quality regarding fatty acid composition by increasing the palmitic, palmitoleic, and linoleic acid contents.

\section{Acknowledgments}

This work was carried out with the support of the "Cooperative Research Program for Agriculture Science and Technology Development (Project no. PJ01028303)", Rural Development Administration, Republic of Korea. The authors are thankful to Austin Thelen (Oregon State University, USA) and Lindsay A. Loehden (Linfield College, USA) for their help in English editing the manuscript.

\section{References}

AOAC - Association of Official Analytical Chemists. 1990. Official methods of analysis. 15th ed. Association of Official Analytical Chemists, Washington, DC, USA.

Belury, M. A. 2002. Dietary conjugated linoleic acid in health: Physiological effects and mechanisms of action. Annual Review of Nutrition 22:505-531.

Chin, S. F.; Liu, W.; Storkson, J. M.; Ha, Y. L. and Pariza, M. W. 1992. Dietary sources of conjugated dienoic isomers of linoleic acid, a newly recognized class of anticarcinogens. Journal of Food Composition and Analysis 5:185-197.

Folch, J.; Lee, M. and Sloane-Stanley, G. H. 1957. A simple method for the isolation and purification of total lipids from animal tissues. Journal of Boilogical Chemistry 226:497-509.

French, P.; Stanton, C.; Lawless, F.; O’Riordan, E. G.; Monahan, F. J.; Caffrey, P. J. and Moloney, A. P. 2000. Fatty acid composition, including conjugated linoleic acid, of intramuscular fat from steers offered grazed grass, grass silage, or concentrate-based diets. Journal of Animal Science 78:2849-2855.

Ghassemi Nejad, J.; Lohakare, J. D.; West, J. W.; Kim, B. W.; Lee, B. H. and Sung K. I. 2015. Effects of water restriction following feeding on nutrient digestibilities, milk yield and composition and blood hormones in lactating Holstein cows under heat stress conditions. Italian Journal of Animal Science 14:479-483. 
Ghassemi Nejad, J.; Lohakare, J. D.; West, J. W. and Sung, K. I. 2014. Effects of water restriction after feeding during heat stress on nutrient digestibility, nitrogen balance, blood profile and characteristics in Corriedale ewes. Animal Feed Science and Technology 193:1-8.

Ghassemi Nejad, J.; Hosseindoust, A.; Shoae, A.; Ghorbani, B.; Lee, B. H.; Oskouian, E.; Hajilari, D.; Amouzmehr, A.; Lohakare, J. D. and Sung, K. I. 2013. Effects of feeding level of starter on weaning age, performance, nutrient digestibility and health parameters in Holstein dairy calves. Asian Australasian Journal of Animal Science 26:827-830.

Ghassemi Nejad, J.; Torbatinejad, N.; Naserian, A. A.; Kumar, S.; Kim, J. D.; Song, Y. H.; Ra, C. S. and Sung, K. I. 2012. Effects of processing of starter diets on performance, nutrient digestibility, rumen biochemical parameters and body measurements of Brown Swiss dairy calves. Asian Australasian Journal of Animal Science 25:980-987.

Ghassemi Nejad, J.; Lee, B. H.; Kim, B. W.; Ohh, S. J. and Sung, K. I. 2016. Effects of chromium methionine supplementation on blood metabolites and fatty acid profile of beef during late fattening period in Holstein steers. Asian Australasian Journal of Animal Science 29:378-383.

Goering, H. K. and Van Soest, P. J. 1991. Forage fiber analyses (apparatus, reagents, procedures, and some applications). Agric. Handbook. No.379. ARS, USDA, Washington, DC.

Kinser, A. R.; Fahey, G. C.; Berger, L. L. and Merchen, N. R. 1988. Low-quality roughages in high-concentrate pelleted diets for sheep: Digestion and metabolism of nitrogen and energy as affected by dietary fiber concentration. Journal of Animal Science 66:487-500.

Kitchalong, L.; Fernandez, J. M.; Bunting, L. D.; Southern, L. L. and Bidner, T. D. 1995. Influence of chromium tripicolinate on glucose metabolism and nutrient partitioning in growing lambs. Journal of Animal Science 73:2694-2705.

Lindemann, M. D.; Cromwell, G. L.; Monegue, H. and Pursur, K. W. 2008. Effect of chromium source on tissue concentration of chromium in pigs. Journal of Animal Science 86:2971-2978.

Littell, R. C.; Henry, P. R. and Ammerman, C. B. 1998. Statistical analysis of repeated measures data using SAS procedures. Journal of Animal Science 76:1216-1231.

Melton, S. L.; Amiri, M.; Davis, G. W. and Backus, W. R. 1982. Flavor and chemical characteristics of ground beef from grass-, forage-grain-and grain-finished steers. Journal of Animal Science 55:77-87.

Merchen, N. R.; Firkins, J. L. and Berger, L. L. 1986. Effect of intake and forage level on ruminal turnover rates, bacterial protein synthesis and duodenal amino acid flows in sheep. Journal of Animal Science 62:216-225.

NRC - National Research Council. Nutrient requirements of beef cattle. 2000. 7th rev. ed. National Academy Press, Washington, DC, USA.

Ohh, S. J. and Lee, J. Y. 2005. Dietary chromium-methionine chelate supplementation and animal performance. Asian Australasian Journal of Animal Science 6:898-907.

Ohh S. J.; Kim, C. H.; Shin, J. S.; Sung, K. I. and Kim, H. S. 2004. Effects of different forms of Chromium supplements on serum glucose, insulin and lipids in rats. Journal of Food Science and Nutrition 9:342-345.

Smith, S. B.; Gill, C. A. and Lunt, D. K. 2009. Regulation of fat and fatty acid composition in beef cattle. Asian Australasian Journal of Animal Science 22:1225-1233.

Song, S. Y.; Ghassemi Nejad, J.; Ohh, S. J.; Lee, B. H.; Kim, H. S. and Sung, K. I. 2013. Effects of chromium-methionine chelate feeding for different duration on growth and carcass characteristics of Holstein steers in the late fattening stage. Annals of Animal Resource Sciences 24:38-43.

Sung, K. I.; Ghassemi Nejad, J.; Hong, S. M.; Ohh, S. J.; Lee, B. H.; Peng, J. L.; Ji, D. H. and Kim, B. W. 2015. Effects of forage level and chromium-methionine chelate supplementation on performance, carcass characteristics and blood metabolites in Korean native (Hanwoo) steers. Journal of Animal Science and Technology 57:14-20.

Zea, S. J.; Diaz, M. D. D. and Santaolalla, J. A. C. 2007. Sex and beef production system on meat and fat quality. Archivos de Zootecnia $56: 817-828$

Zinn, R. A. and Plascencia, A. 1996. Effects of forage level on the comparative feeding value of supplemental fat in growing-finishing diets for feedlot cattle. Journal of Animal Science 74:1194-1201.

Zinn, R. A.; Plascencia, A. and Barajas, R. 1994. Interaction of forage level and monensin in diets for feedlot cattle on growth performance and digestive function. Journal of Animal Science $72: 2209-2215$ 